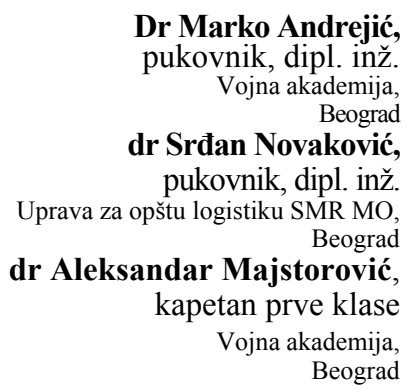

Dr Marko Andrejić pukovnik, dipl. inž. Vojna akademija,

dr Srđan Novaković, pukovnik, dipl. inž. Uprava za opštu logistiku SMR MO, Beograd

dr Aleksandar Majstorović, kapetan prve klase Vojna akademija, Beograd

\section{PLANIRANJE U VOJNIM ORGANIZACIONIM SISTEMIMA}

UDC: $65.012 .2: 355.1$

Rezime:

U radu se razmatra planiranje kao inicijalna upravljačka funkcija u vojnim organizacionim sistemima i planiranje kao proces. Obrađena je suština planiranja, ciljevi koje treba dostici, rezultati koje treba ostvariti i zadaci koje treba realizovati putem planiranja. Identifikovani su planovi u vojnim organizacionim sistemima i model izrade planova. Sagledani su subjekti planiranja i njihove obaveze i faktori koji utiču na planiranje. Sistematizovani su nedostaci planiranja u vojnim organizacionim sistemima, obrađeni principi planiranja, kao $i$ planiranje konkretnog zadatka i ukazano na softver za podršku pojedinih faza.

Ključne reči: planiranje, funkcija planiranja, proces planiranja, principi planiranja, vrste planova, obeležja planova, upravljanje putem planiranja, podrška planiranju.

\title{
PLANNING IN MILITARY ORGANIZED SYSTEMS
}

Summary:

The paper deals with planning as an initial managing function in military organized systems as well as with planning as a process. The very essence of planning has been considered along with targeted goals, tasks to be fulfilled through planning and attainable results. Plans in military organized systems and a plan formulation model being identified, planning subjects and their duties have been discussed as well as planning-influencing factors. The paper also gives a systematic presentation of drawbacks of planning in military organized systems, principles of planning, planning of particular tasks and a software for logistic support of particular planning phases.

Key words: planning, function of planning, process of planning, principles of planning, types of planning, characteristics of planning, management by planning, planning logistics.

\section{Uvod}

Planiranje u vojnim organizacionim sistemima vrlo je značajno za uspešnost poslovanja funkcionisanja i razvoja sistema, a njegove slabosti se brzo uočavaju i dugoročno utiču na sistem. Planiranje je inicijalna i vrlo bitna upravljačka funkcija $\mathrm{u}$ vojnim organizacionim sistemima. Vrši se zbog neodređenosti, neizvesnosti i promena koje postoje u organizacionim sistemima i okruženju.
Kvalitetnim planiranjem izbegava se da sistem dođe u neželjeno stanje, a ako, ipak, dođe da posledice budu što manje i da se što pre saniraju. Planiranjem se bave pojedinci i organizovane grupe, a najbolje je ako se obavlja timski. Poznavanje teorijskih osnova planiranja potrebno je svim subjektima upravljanja, rukovođenja i komandovanja (upravnicima, načelnicima, komandantima, komandirima...). Planiranje mora biti zastupljeno u svim fazama životnog ciklusa vojnih organizacionih si- 
stema (mir, krizne situacije, vanredno stanje, neposredna ratna opasnost, mobilizacija, ratno stanje).

Da bi se kvalitetno planiralo neophodno je poznavati teoriju planiranja, savremene metode, tehnike, softver i opremu za podršku planiranju, posao koji se planira, odnosno podsisteme i procese složenog sistema, relevantne faktore i elemente situacije (u sistemu i okruženju) i njihove moguće konstelacije $u$ predviđenoj budućnosti. Za dobro planiranje potreban je odgovarajući broj, vrsta i kvalitet podataka. Saznanja iz prakse pokazuju da se teorijske osnove planiranja moraju izučavati u većoj meri i više poznavati i da se planiranje ne sme posmatrati kao parcijalna rutinska delatnost u trenutku nužnosti, već kao stalan proces kreativnog rešavanja problema.

U našoj novijoj teoriji i praksi planiranje nije dovoljno istraživano, a ni definisano, ni sa organizacionog ni sa tehnološkog aspekta. Samim tim, i mogućnosti za unapređenje planiranja nedovoljno su razmatrane u našoj teoriji i praksi. Određeni indikatori trenutnog stanja, koji su u velikoj meri posledica neadekvatnog planiranja, zatim potreba prakse, zahtevi vremena i savremeni upravljački trendovi, ukazali su na potrebu da se ovaj važan segment vojnih organizacionih sistema više rasvetli i unapredi, u organizacionoj i tehnološkoj sferi.

Aspekti i faze planiranja su zajednički (isti) pri planiranju bilo kog složenog posla u vojnim organizacionim sistemima, dok su sadržaji planiranja, obim, forma i sadržaj planskih instrumenata uslovljeni misijom i namenom konkretnog organizacionog sistema i vrstom posla kojim se bavi.
Planiranje se ne može istraživati i u praksi sprovoditi ako se ne poznaju njegova bitna obeležja kao funkcije u organizacionim sistemima i bitna obeležja planiranja kao procesa. ${ }^{1}$ Kvalitetne pripreme za planiranje vrlo su važan preduslov za njegovu uspešnu realizaciju, što zahteva da i planiranje bude planirano.

Pri razmatranju planiranja u vojnim organizacionim sistemima primenjivaće se izvesna analogija sa klasičnim pristupom planiranju u ostalim organizacionim sistemima, ali će se koristiti i pristup primereniji postojećem tehničko-tehnološkom razvoju, zasnovan na određenim dostignućima projekt-menadžmenta i organizacionih nauka.

Izbor adekvatnih ciljeva koje treba dostići, donošenje optimalnih odluka o rezultatima koje treba ostvariti i zadacima koje treba realizovati uz optimalno angažovanje resursa, te adekvatno prezentovanje ciljeva i odluka zainteresovanim subjektima sve više će se, pod uticajem javnosti, tražiti od menadžmenta, stručnih službi i planskih organa u vojnim organizacionim sistemima.

U ovom radu će se određeni aspekti i segmenti planiranja obrađivati sa visokim stepenom uopštavanja, oslanjajući se na iskustva autora, istraživanja u kojima su učestvovali i na dostupne izvore znanja. Navedeni pristup omogućava veću generalnost izrečenih stavova, a sa druge strane može dobiti i na snazi (dubini i preciznosti) ukoliko se valjano operacionalizuje na svaki konkretan slučaj.

\footnotetext{
Uočava se da se savremeni vojni rukovodioci u svom radu uglavnom orijentišu na organizacionu strukturu i na ljude, a da u manjoj meri poznaju tehnologiju procesa koji se odvijaju u organizacionim sistemima. Potrebe prakse, zahtevi vremena i savremeni trendovi u menadžmentu zahtevaju određene zahvate u sferi edukacije rukovodioca u smislu boljeg ovladavanja organizaciono-tehnološkim procesima.
} 
Cilj ovog rada jeste da se, u sintetizovanoj formi, ukaže na nedostatke postojećeg planiranja, iznesu određene teorijske osnove planiranja značajne za vojne organizacione sisteme, radi davanja doprinosa unapređenju planiranja u operativnoj praksi i animiranja planera iz prakse da svoja iskustva iznose sudu šire javnosti, kako bi se obogaćivala praksa planiranja, sakupljena građa verifikovala u naučnoj proceduri i ponovo sistemski uvodila u operativnu praksu.

\section{Nedostaci planiranja u vojnim organizacionim sistemima}

Postojeća teorijska razrađenost planiranja u našoj vojnoj teoriji ne predstavlja u dovoljnoj meri solidnu polaznu osnovu za njegovo efikasnije sprovođenje u praksi. Kritičkim i analitičko-sintetičkim sagledavanjem postojeće teorije i prakse planiranja $u$ vojnim organizacionim sistemima moguće je identifikovati čitav niz propusta (u manjoj ili većoj meri) u planiranju.

Postojeći način planiranja nije potpuno zasnovan na naučnoj osnovi, uz primenu naučnih principa planiranja, naučnih metoda, tehnika, softvera i informatičke opreme. Sistemski pristup u planiranju nedovoljno se primenjuje, a ne usklađuju se ni aktivnosti različitih subjekata odgovornih za planiranje, pripremu, sprovođenje i analizu procesa. Zbog odsustva dugoročnog koncepta sa ugrađenim organizacionim aspektom i kreativnosti u planiranju, ono je postalo parcijalna delatnost koja se često obavlja površno i rutinski u trenutku nužnosti.
Objekti planiranja ne sagledavaju se dinamički kroz ceo životni ciklus. Pri izradi planova insistira se na „nemogućim rešenjima“" (insistiranje na uvažavanju kriterijuma bez respektovanja ograničenja organizacione i tehnološke prirode). Pravo na odlučivanje se tokom planiranja često poistovećuje sa tehnologijom odlučivanja, što ima za posledicu isključivanje stručnih organa iz procesa donošenja odluka. Najodgovorniji ljudi u sistemu nedovoljno se uključuju u proces planiranja, jer pojedinci smatraju da je planiranje posao operativnih i planskih organa, što ima za posledicu odsustvo pravih informacija pri donošenju odluka, nestalnost u radu upravnih i izvršnih struktura (narušavanje standardnih postupaka $u$ radu) i pojavu velikog broja ,vanrednih zadataka". 2

Postojeći način planiranja u vojnim organizacionim sistemima ne omogućava optimalno korišćenje svih raspoloživih umnih i drugih potencijala u sistemu. Neadekvatna primena i nedovoljno poznavanje timskog rada, načela, logike i metoda planiranja, uslovljava sektorski pristup planiranju. Planiranje brojnih procesa nije metodološki razrađeno na jedinstven način (kao koherentna celina), pa u praksi ima različitosti u pristupu ovoj problematici, što je, sa aspekta jedinstvenog sistema komandovanja, neopravdano i štetno. U planskim rešenjima se, često, ne ističe stepen značajnosti elemenata rešenja (aktivnosti, zadataka i sl.), težišta i prioriteti.

${ }^{2}$ Rukovodioci nerado planiraju, naročito dugoročno, jer su svesni obima i vrste nepoznanica sa kojima se susreću. S druge strane, iskustvo ih uči da se i najsavesnije izrađeni planovi retko ostvaruju. 
Sve faze, aspekti i dimenzije složenih pojava i procesa se ne uočavaju i ne uvažavaju u dovoljnoj meri. Organizacioni planovi se nedovoljno (hijerarhijski i lateralno) uvezuju, jer se planska rešenja ne posmatraju sa upravljačkog aspekta. Organizacioni sistemi, pojave i procesi u njima ne posmatraju se sveobuhvatno i multidisciplinarno. Međusobni uticaj pojedinih faza životnog ciklusa ne uvažava se u dovoljnoj meri, naročito pri iznalaženju optimalnih rešenja. Kao kreativan proces, planiranje se često poistovećuje sa izradom planskih dokumenata, odnosno ispunjavanjem formalizovanih obrazaca.

Iskustva iz prethodnog perioda ukazuju na to da se uz elaborate koji su proizvod planiranja ne čuvaju analize koje se odnose na realizaciju planova. ${ }^{3}$ Planska rešenja se ne rade za najnepovoljniju varijantu izvršenja zadatka, a često se, bez kvantifikovanja merljivih faktora, izrađuju za samo jednu varijantu izvršenja. ${ }^{4}$ Nizak nivo interne standardizovanosti podataka, neefikasna razmena podataka na izvršnom nivou i relativno nisko iskorišćenje umnih potencijala i opreme $u$ organizacionim sistemima opterećuje planere i sputava njihovu kreativnost.

Odsustvo permanentnog osvežavanja znanja potrebnih za planiranje, nedovoljna popunjenost uprava i komandi starešinskim kadrom i informatičkom opremom, ustaljeni načini rada na planiranju $i$ rešavanju problema $\mathrm{i}$ intenzivni dnevni

\footnotetext{
Navedene analize mogle bi korisno da posluže za unapređenje procesa planiranja i spreče da se jednom učinjene greške ponavljaju.

Time se svesno izbegava ulaženje u suštinu problema i stvara osećaj privida u vlastitom polju odgovornosti. Većina rešenja do kojih se dolazi planiranjem su višekriterijumske prirode i zahtevaju, pri traženju optimuma, uzimanje u obzir ograničenja i težine svakog kriterijuma ponaosob.
}

operativni zahtevi usložavaju i otežavaju planiranje, tako da se praksa zadržava na dnevnom obezbeđenju funkcionisanja sistema, a ne i na stalnoj težnji ka povećanju progresa i efikasnosti.

Planovi organizacionih sistema na današnjem nivou razvitka planske metodologije još ne predstavljaju podlogu za nastanak (konstituciju) i funkcionisanje svih postojećih organizacionih sistema. U njihovoj izradi najdalje se otišlo u ekonomskoj oblasti, ali oni sve više prodiru i u druge društvene aktivnosti [1].

Zbog izvesne ograničenosti planiranja u vojnim organizacionim sistemima, pri realizaciji određenih aktivnosti plana može nastupiti određeni nesklad između činilaca organizacionih procesa, koji je bio uspostavljen da bi se ostvarili određeni rezultati.

Do narušavanja odnosa dolazi zbog sledećih razloga:

- planovima se ne može sve predvideti, a često se i plan ne uradi najbolje, pa se greške u toku realizacije manifestuju kao neusklađenost između osnovnih činilaca procesa,

- $\mathrm{u}$ toku realizacije procesa dolazi do novih momenata: od sitnih objektivnih teškoća manjih razmera, raznih unutrašnjih i spoljnih smetnji, pa do krupnih pojava „više sile“,

- planovi se ne izvršavaju ravnomerno, a to narušava ritam procesa, vertikalnu usklađenost i dovodi do pojave disproporcija. ${ }^{5}$

Upravljački i planski organi treba da budu svesni navedenih činjenica i da na-

Disproporcije smanjuju efikasnost, pa su zbog toga potrebne brze taktičke, rutinske odluke rukovodioca na licu mesta, u skladu sa ranije definisanim ovlašćenjima. 
stoje da kroz adekvatna rešenja utiču na smanjenje ovih nepoželjnih, ali realno mogućih pojava.

\section{Funkcija planiranja u vojnim organizacionim sistemima}

Planiranje $\mathrm{u}$ vojnim organizacionim sistemima jedna je od najvažnijih funkcija upravljačkog procesa. Funkcija planiranja obuhvata aktivnosti usmerene na:

- donošenje odluka o ciljevima koji se žele postići, rezultatima koje treba ostvariti i zadacima koji se moraju izvršiti,

- utvrđivanje politike za ostvarenje željenih ciljeva,

- izbor strategije za ostvarenje ciljeva,

- izradu planova, kao upravljačkih instrumenata, za realizaciju ciljeva.

Sadržaj funkcije planiranja u organizacionim sistemima svodi se na aktivnosti menadžmenta i planskih organa. $\mathrm{Za}$ realizaciju obe vrste aktivnosti odgovoran je menadžment organizacije.

Osnovu za planiranje u vojnim organizacionim sistemima predstavljaju:

- formulisani ciljevi organizacije za predstojeći period i kriterijumi za ciljna rešenja,

- jasno definisanje pokazatelja uspešnosti sistema u procesu dostizanja ciljeva,

- informacije o ostvarenju zadataka (plana) u proteklim periodima i trenutnom stanju sistema u trenutku planiranja,

- informacije (tehnička, logistička, operativna i druga dokumentacija) o raspoloživim uslovima za predstojeće aktivnosti (ograničenja),

- razrađeni scenario budućnosti u kojoj će se sistem naći tokom dostizanja cilja.
Planiranje $\mathrm{u}$ vojnim organizacionim sistemima usmereno je na predviđanje [1]: budućeg stanja sistema na kraju definisanog planskog perioda; budućeg ponašanja; uslova koji su potrebni da bi se ostvarila planirana stanja ili ponašanja sistema (materijal, radna snaga, informacije, energija, finansijska sredstva), i redosleda i vremena tokova aktivnosti.

Planiranje kao delatnost sa primenjenim metodama, tehnikama i softverom mora biti: celovito, kontinuirano i metodološki ujednačeno.

Funkcija planiranja $\mathrm{u}$ vojnim organizacionim sistemima zasniva se na kriterijumima koje uslovljava okruženje (u periodu u kojem se planira) sa svim svojim zakonitostima i manifestacijama, kao i ograničenjima koja proističu iz samog sistema (kadrovska, materijalna, finansijska, prostorna, vremenska, informaciona, ograničenja energetske prirode $\mathrm{i} d r$.). Zbog navedenih razloga planiranje se zasniva na informacijama koje se dobijaju od organa koji se bave pojedinim funkcijama, odnosno aspektima sistema.

Sadržaj funkcije planiranja u vojnim organizacionim sistemima podrazumeva aktivnosti upravljačkih i planskih organa, te aktivnosti stručnih službi.

Poslovi upravljačkih organa (menadžmenta) obuhvataju sledeće aktivnosti, vezane za planiranje: utvrđivanje misije, vizije, ciljeva, težišta, prioriteta i standarda; izbor politike za ostvarenje ciljeva; izbor strategije za ostvarenje ciljeva; definisanje zadataka nosilaca pojedinih funkcija izvršenja; definisanje planskih kriterijuma i ograničenja; definisanje bezbednosne zaštite procesa planiranja i planova; praćenje realizacije plani- 
ranih ciljeva radi uspostavljanja ravnoteže između planiranih rezultata i promenjenih uslova za ostvarenje plana i analiza realizacije planova.

Planski organi odgovorni su da odluke o ciljevima, merama i akcijama za ostvarenje ciljeva stručno artikulišu, oblikuju i iskažu kroz odgovarajući dokument - plan, kao instrument funkcije planiranja. Primenom naučnih metoda, tehnika i savremene informatičke i druge opreme, te uvažavanjem principa poslovanja, planski organi izrađuju određena dokumenta (planske instrumente - planove), koji sadrže obrazloženja i kvantifikacije planiranih rezultata i uslova za njihovo ostvarivanje.

Stručne službe rade na analizi problema i na razvijanju više varijanti rešenja. Ostale organe u sistemu snabdevaju stručnim analizama, podacima, dokumentacijom, informacijama o činjenicama, pojavama i tendencijama koje su neophodne za donošenje načelnih odluka o poslovnoj politici sistema. Stručne službe nemaju ovlašćenja ni direktnu odgovornost za donošenje odluka. Njihova odgovornost je indirektne prirode, jer odgovaraju za ispravnost i stručnost dokumentacije koja služi kao osnova za donošenje odluka u procesu planiranja.

Tokom planiranja $u$ vojnim organizacionim sistemima mora se voditi računa o sledećim faktorima:

- odbrambeno-bezbednosni: obim i struktura ukupnih odbrambenih i bezbednosnih resursa, odnosno potencijala, a posebno u nadležnosti (zoni angažovanja, odgovornosti ili interesa) razmatranog sistema, sa svim kvalitativnim i kvantitativnim karakteristikama koje utiču na aktivnosti sistema;
- vojno-sistemski (pravne norme i akta i druge norme i mere nadležnih organa koje deluju podsticajno ili ograničavajuće na planiranje i izvršavanje zadataka);

- materijalni i tehničko-tehnološki elementi izvršenja zadataka (opremljenost opremom i kvalitet opreme, karakteristike tehnološkog postupka, zadataka i uslova rada);

- kadrovski (količina, vrsta, kvalifikaciona struktura, stepen obučenosti kadra, pouzdanost kadra, itd.);

- organizacioni (mere koje upravljački organi preduzimaju radi postizanja visoke uspešnosti poslovanja putem obezbeđenja korišćenja objektivnih uslova za izvršenje zadataka, efektivno i efikasno);

- prostorni (specifičnost otvorenog i zatvorenog prostora na kojem se izvršavaju zadaci: kvalitet podloge, površina, nosivost, međusobne udaljenosti prostornih punktova, pokrivenost rastinjem, naseljenost, infrastruktura, itd.);

- vremenski (u svim modalitetima i pojavnim oblicima).

Uvažavanje navedenih faktora obezbeđuje realnost planiranja i omogućava da plan predstavlja obavezujući i motivišući materijalni dokument.

Planiranje kao proces rešavanja organizacionih problema karakterišu sledeći aspekti: organizacioni, metodološki, komunikacioni, međuljudski i funkcionalni (sadržajni). Potpuno ovladavanje navedenim aspektima, znatno doprinosi kvalitetu planiranja.

Putem procesa planiranja u vojnom organizacionom sistemu treba doći do: željenih ciljeva; vrsta i obima aktivnosti koje treba realizovati na putu dostizanja 
ciljeva; problema i opasnosti u pogledu dostizanja ciljeva (naše snage, protivnik, prostor, vreme, konkurenti i različiti modaliteti kombinacija navedenih faktora); organizacionih mera, postupaka i aktivnosti kojima se iskorišćavaju ,šanse“ iz okruženja, a smanjuju potencijalne ,,pretnje“ i posledice ostvarenih pretnji po sistem, živu silu, prostor i materijalna sredstva; potrebnih resursa; kvalitetnih organizacionih rešenja (način i dinamika realizacije određenih aktivnosti); težišta $\mathrm{u}$ ukupnim naporima i prioriteta $\mathrm{u}$ dinamici (vremenu) realizacije aktivnosti; organizacionih rešenja koja obezbeđuju skladno korišćenje resursa u prostoru, vremenu i konkretnoj situaciji.

Pri planiranju složenih poslova $\mathrm{u}$ vojnim organizacionim sistemima uočavaju se tri grupe problema:

- problemi koji se mogu uspešno rešavati pomoću formalizovanih postupaka (algoritama);

- problemi koji se mogu na zadovoljavajući način rešavati korišćenjem savremenih tehnologija (softver, hardver, netver);

- problemi koji se mogu rešavati zahvaljujući ljudskom potencijalu, specifičnom znanju, emocijama, iskustvu, intuiciji i sposobnosti da se brzo identifikuju ključni činioci i pretraže moguće varijante $u$ nestandardizovanim problemima.

Na planiranje u vojnim organizacionim sistemima utiču brojna organizaciona i tehnološka ograničenja. Organizaciona ograničenja predstavljaju pravne norme i pravni akti, uredbe, pravila, uputstva, planovi, naređenja i smernice koje se dobijaju od višeg sistema. ${ }^{6}$ Teh-

${ }^{6}$ Sve je deo celine i celina delova. nološka ograničenja pri planiranju čini sama suština (priroda) procesa koje realizuje konkretni organizacioni sistem i koja zahteva da se aktivnosti odvijaju u određenom vremenu, po određenoj tehnologiji i uz utrošak određenih resursa.

Pri planiranju složenih poslova tretiraju se sledeći elementi: zadaci - aktivnosti (određivanje logičke međuzavisnosti aktivnosti i određivanje protoka izlaznih parametara prethodne aktivnosti $\mathrm{u}$ ulazne parametre narednih aktivnosti), resursi (važni za realizaciju zadatka), rokovi (početak, završetak, vremenska rezerva) i kvalitet izvršenja zadatka.

Planiranje se zasniva na podacima i informacijama koje se koriste u toku logičke analize i primene tehnika, metoda i modela planiranja. Podaci koji se koriste u procesu planiranja treba da imaju sledeća obeležja kvaliteta: reprezentativnost (važnost za primaoca), verodostojnost (pouzdanost), blagovremenost, potpunost, preciznost, razumljivost, adekvatna forma (oblik) prezentovanja i adekvatna otvorenost (transparentnost).

Rad na predviđanju i donošenju perspektivnih planova u praksi se odvija na različite načine, u zavisnosti od konkretnog organizacionog sistema, dok je postupak rada na donošenju osnovnih planova najčešće ustaljen i razrađen u izvestan broj faza koje se smenjuju po određenom logičnom redosledu [1]:

1. Pribavljanje informacija o stanjima, ponašanjima ili redosledu akcija $u$ proteklim planskim periodima sistema.

2. Pribavljanje informacija o objektivnim pretpostavkama i subjektivnim faktorima koji će da deluju u planskom periodu za koji se obavlja planiranje. 
3. Proveravanje realnih uslova za ostvarenje rezultata i dostizanje zadatih ciljeva koji se definišu i postavljaju kao zadatak aktom planiranja.

4. Izrada projekta plana (razvijanje planova).

5. Organizaciono uvezivanje plana sa ostalim organizacionim planovima sa kojima postoji međuzavisnost i njihovo uravnoteženje.

6. Lansiranje (distribucija) planova.

7. Unošenje završnih korekcija i konačno donošenje planova.

8. Kontrola donošenja planova. planova.

9. Praćenje i kontrola realizacije

Podaci potrebni za planiranje prikupljaju se iz postojećih statističkih izvora (analiza), od državnih organa i organizacija, vojnih, tržišnih i ostalih procena i procesa. Prikupljeni podaci se selektuju po vrstama i značaju informacija, kako bi se eliminisao suviše veliki i nepotreban broj podataka. Nakon selekcije podataka obavlja se njihova analiza, naročito analiza pouzdanosti.

Razvijanje planova je, u stvari, njihovo oblikovanje i izrada za konkretan sistem. U izradi planova koriste se $\mathrm{i}$ interni podaci iz organizacionog sistema, kao što su: završne godišnje analize poslovanja (opremanja, upotrebe), analize borbene gotovosti, ugovoreni poslovi, prelazne obaveze, najavljene kupovine, itd. Lansiranje planova podrazumeva njihovo dostavljanje sa pomoćnim podacima i potrebnim objašnjenjima odgovarajućim organima na operacionalizaciju. $U$ procesu realizacije planova neophodno je kontrolisati i njihovu realizaciju, i to po: rokovima, troškovima, mestu, nosiocima, kvalitetu, itd. Odstupanje realizacije plana od njegove misaone konstrukcije mora biti predmet stalne analize.

Planiranje konkretne aktivnosti daje odgovore na sledeća pitanja: ko, šta, kako, kada, gde, s kim, čim i zašto treba učiniti, da bi izvršili zadatak u skladu sa zadatim zahtevima (kriterijumima) i uslovima (ograničenjima). ${ }^{7}$

Nezavisno od toga koje se metode $\mathrm{i}$ tehnike koriste, operativno planiranje konkretnog zadatka obuhvata određene aktivnosti u okviru definisane strukture, toka i alokacije resursa. To su:

- trajanje pojedinih aktivnosti,

- broj i kvalifikacija izvršilaca i njihovo nominovanje,

- količina i vrsta opreme, materijala, sitnog inventara i drugih resursa,

- tehnička pomagala, oprema i uređaji,

- vremensko korišćenje uređaja i opreme,

- finansijska sredstva i njihova distribucija,

- rokovi završetka.

\section{Vrste i obeležja planova u vojnim organizacionim sistemima}

Klasifikacija planova u vojnim organizacionim sistemima može se obavljati u odnosu na sledeće kriterijume: ${ }^{8}$

- period za koji se izrađuje (horizont planiranja): dugoročni, srednjoročni i kratkoročni;

\footnotetext{
Samo u izuzetnim slučajevima planovi sadrže odgovore i na pitanja „zašto“.

Važno je naglasiti da se ovi kriterijumi međusobno ne isključuju i da demarkaciona linija između njih ne mora uvek biti jasna.
} 
- nivo organizacione celine koji vrši planiranje $i$ dalekosežnost posledica usvojenih - donetih planova: strategijski, operativni i taktički;

- vrsta sistema koji tretiraju: tehnički i organizacioni;

- faza životnog ciklusa sistema na koju se odnosi: mirnodopski planovi, planovi za krizne situacije, planovi za postupanje $u$ vanrednom stanju, planovi za postupanje u stanju neposredne ratne opasnosti, ratni planovi;

- namenski ciljevi sistema: planovi odbrane i zaštite vitalnih bezbednosnih i odbrambenih interesa, planovi za očuvanje mira i razvijanje povoljnog bezbednosnog okruženja, planovi razvijanja i unapređenja partnerskih odnosa sa institucijama sistema kolektivne bezbednosti, susednim i drugim državama;

- objektni ciljevi sistema: planovi upotrebe, planovi razvoja, planovi rada; ${ }^{9}$

- sadržaj koji tretiraju: planovi ponašanja, ${ }^{10}$ planovi budućih stanja ${ }^{11} \mathrm{i}$ planovi uslova potrebnih za ostvarenje planiranih stanja i ponašanja sistema;

- objekat na koji se odnosi - obim i nivo sistema na koji se odnosi: plan Vojske u celini, planovi organizacionih celina, ${ }^{12}$ pojedinačni - lični;

\footnotetext{
${ }^{9}$ Po ovom kriterijumu planovi se mogu deliti, s obzirom na radove, na konkretne - tekuće operativne planove kojima se stvaraju uslovi za ostvarenje namenskih ciljeva.

${ }^{10}$ Planovima ponašanja sistema predviđaju se određene faze aktivnosti dinamičkog sistema. Najčešći planovi ponašanja ekonomskih sistema su: operativni plan proizvodnje (radova i usluga) i operativni finansijski plan.

Kod statičkih sistema, kao što su mnogi tehnički sistemi, to su stanja njihove konstitucije, odnosno strukture njihovih elemenata i međusobnih odnosa između tih elemenata tehnički projekti. Kod dinamičkih sistema, kao što su ekonomski i drugi sistemi to su odnosi između elemenata izlaza iz sistema i elemenata ulaza u sistem, zahvaćeni određenim vremenskim presekom - u jednoj godini, u više godina i sl.

12 Organizacioni planovi se dalje mogu deliti prema organizacionoj pripadnosti ili prema funkcijama u organizaciji.
}

- elementi koji se planiraju: materijalna sredstva (plan materijala), radna snaga (plan radne snage), finansijska sredstva (plan troškova, plan investicija), informacione potrebe, energetske potrebe, prostor, vreme, proizvodi, radovi i usluge, mere i postupci;

- obim aktivnosti čiju realizaciju plan reguliše: osnovni i dopunski;

- karakteristike plana: kvalitativni, kvantitativni, itd.

Predviđanje budućeg stanja vojnog organizacionog sistema predstavlja se kroz osnovne planove, kao stanje rezultata rada (razvoja, upotrebe, obuke, proizvodnje, radova i usluga) sistema u određenom periodu, izraženo odnosom izlaza i ulaza u sistem.

Predviđanje budućeg ponašanja sistema predstavlja se operativnim planovima kroz preseke niza stanja sistema $u$ vremenu, koja predstavljaju direktan izraz akata ponašanja. Ovi planovi su izraz željenog ponašanja organizacionog sistema u dinamici, a rade se za kraće periode (najčešće za mesec dana), jer zahtevaju viši stepen preciznosti, za razliku od osnovnih planova, koje je teško odrediti za duži period.

Predviđanje potrebnih uslova, kao nužnih pretpostavki za ostvarenje planiranih stanja i ponašanja sistema, podrazumeva planiranje potrebnog rada, radne snage (rukovodioci i izvršioci), materijalnih i finansijskih sredstava.

$\mathrm{S}$ obzirom na horizont planiranja, $u$ literaturi se sreću sledeće etape (faze) razvijanja planova: predviđanje; perspektivno planiranje; srednjoročno planiranje; operativno planiranje, i terminiranje.

Glavna obeležja navedenih planova [8] prikazana su u tabeli. 
Glavna obeležja planiranja po vrstama

\begin{tabular}{|c|c|c|c|c|}
\hline $\begin{array}{l}\text { OBELEŽJE } \\
\text { PLANIRA- } \\
\text { NJA } \\
\text { VRSTA } \\
\text { PLANIRANJA }\end{array}$ & $\begin{array}{c}\text { HORIZONT } \\
\text { PLANIRANJA }\end{array}$ & $\begin{array}{l}\text { KO OBAVLJA } \\
\text { PLANIRANJE }\end{array}$ & $\begin{array}{c}\text { NA OSNOVU ČEGA SE } \\
\text { OBAVLJA }\end{array}$ & $\begin{array}{l}\text { SADRŽAJ PLANA } \\
\text { (predmet tretiranja) }\end{array}$ \\
\hline 1 & 2 & 3 & 4 & 5 \\
\hline PREDVIĐANJE & Više od 10 godina. & $\begin{array}{c}\text { Multidisciplinarni } \\
\text { timovi. } \\
\text { Konsultanti (eksperti } \\
\text { za scenarije). } \\
\text { Konsultanti (eksperti } \\
\text { za pojedine oblasti). } \\
\text { Najviši organi } \\
\text { upravljanja. }\end{array}$ & $\begin{array}{c}\text { Obavlja se na osnovu podataka } \\
\text { koji se mogu dobiti (saznati, } \\
\text { prozreti, naslutiti, istražiti), na } \\
\text { osnovu globalnih trendova, težnji, } \\
\text { promena i razvoja organizacionih } \\
\text { sistema. Koriste se, uglavnom, } \\
\text { kvalitativne metode, a delom i } \\
\text { kvantitativne (utvrđivanje } \\
\text { trendova). }\end{array}$ & $\begin{array}{c}\text { Definisanje scenarija } \\
\text { budućnosti, projektovanje } \\
\text { budućnosti i usmeravanje } \\
\text { organizacionog sistema ka } \\
\text { budućim promenama. } \\
\text { Predstavlja futurološko } \\
\text { prognoziranje određenih } \\
\text { tokova. }\end{array}$ \\
\hline $\begin{array}{l}\text { PERSPEKTIVNO } \\
\text { PLANIRANJE }\end{array}$ & \begin{tabular}{|c|} 
Period do 10 \\
godina \\
(nedostatak \\
pouzdanih \\
informacija i velika \\
neizvesnost).
\end{tabular} & $\begin{array}{c}\text { Najviši organi } \\
\text { upravljanja u sistemu. }\end{array}$ & $\begin{array}{l}\text { Obavlja se na osnovu globalnih } \\
\text { trendova, težnji, promena i } \\
\text { razvoja organizacionih sistema. }\end{array}$ & $\begin{array}{l}\text { Rast i razvoj sistema. } \\
\text { Globalni pokazatelji obima, } \\
\text { vrste i kvaliteta sistema. }\end{array}$ \\
\hline $\begin{array}{l}\text { SREDNJOROČNO } \\
\text { PLANIRANJE }\end{array}$ & $\begin{array}{l}\text { Period od } 5 \\
\text { godina. }\end{array}$ & $\begin{array}{c}\text { Srednjoročni plan rasta } \\
\text { i razvoja } \\
\text { organizacionog sistema } \\
\text { izrađuje strategijski } \\
\text { menadžment za nivo } \\
\text { celog sistema } \\
\text { (kompanije), kao i za } \\
\text { pojedine njene } \\
\text { autonomne delove. }\end{array}$ & $\begin{array}{c}\text { Vrši se na osnovu perspektivnog } \\
\text { plana, sa korekcijama koje su } \\
\text { rezultat novih saznanja ili } \\
\text { promena. }\end{array}$ & 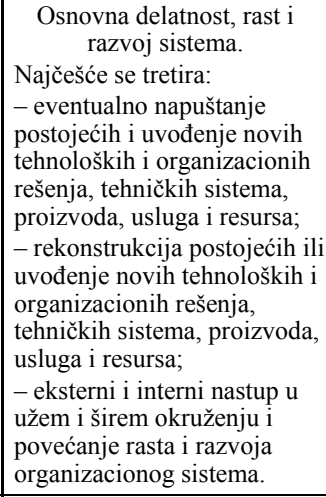 \\
\hline $\begin{array}{l}\text { OPERATIVNO }^{13} \\
\text { PLANIRANJE }^{\text {PLAN }}\end{array}$ & $\begin{array}{c}\text { Najčešće za jedan } \\
\text { mesec, a u } \\
\text { pojedinim } \\
\text { sistemima se } \\
\text { izrađuju i dekadni, } \\
\text { sedmični i dnevni } \\
\text { planovi. }\end{array}$ & \begin{tabular}{|} 
Najviše rukovodstvo \\
sistema (daje smernice \\
i preporuke). \\
Rukovodioci pojedinih \\
organizacionih delova \\
(ili funkcija). \\
Planski organi.
\end{tabular} & $\begin{array}{l}\text { Poslovi iz osnovnog plana, ali i } \\
\text { svi vanredni ili nepredviđeni } \\
\text { radovi ili usluge. }\end{array}$ & \begin{tabular}{|l} 
Ravnomerno se raspoređuje \\
proizvodnja (obuka) ili \\
pružanje usluga, radi \\
optimalnog iskorišćnja \\
resursa i ostvarenja dobiti. \\
Precizno se planira fizički \\
obim radova (proizvodnje, \\
obuke, usluga i sl.) i vrednosni \\
rezultat ostvarenja pojedinih \\
ciljeva. \\
\end{tabular} \\
\hline TERMINIRANJE & \begin{tabular}{|c|} 
Detaljno \\
planiranje dnevnih \\
aktivnosti za jednu \\
smenu ili pojedine \\
delove smene \\
jednočasovno, \\
dvočasovno i sl. \\
\end{tabular} & Svako na svom nivou. & $\begin{array}{l}\text { Poslovi iz operativnog plana, ali i } \\
\text { svi vanredni ili nepredviđeni } \\
\text { radovi ili usluge. }\end{array}$ & \begin{tabular}{|c|} 
Precizno se planira fizički \\
obim radova i drugih \\
aktivnosti i vrednosni rezultat \\
ostvarenja pojedinih ciljeva.
\end{tabular} \\
\hline
\end{tabular}

${ }^{3}$ Fundamentalne elemente operativnih planova čine: ciljevi, akcije, resursi i aktivnosti na određivanju, usmeravanju i motivisanju izvršilaca da realizuju plan.

${ }^{14} \mathrm{Za}$ efikasnost i efektivnost poslovanja (funkcionisanja) vojnih organizacionih sistema posebno su bitni dnevni planovi ličnog an- gažovanja i dnevni planovi organizacionih celina, jer bitno doprinose smanjenju organizacionih gubitaka vremena i resursa

${ }^{15}$ Da bi se uspešno sprovodilo u praksi zahteva postojanje adekvatne organizacione kulture i klime u sistemu. Najviše je zastupljeno u privredi Japana. 


\section{Principi planiranja}

Planiranje podrazumeva primenu određenih principa kao osnove za obezbeđenje efikasnosti i efektivnosti sistema u ostvarenju ciljeva. Na uvažavanje principa se, osim planskim postavkama, mora uticati i tokom realizacije planskih zadataka.

Kvalitetno planiranje podrazumeva pripremu i neposredan rad na planiranju, izbor tehnika i metoda planiranja, koje treba da budu usklađene sa prirodom problema koji se rešava. Za izvršenje zadataka bira se oblik organizovanja koji će obezbediti veću racionalnost, hijerarhijsko dekomponovanje i postupno rešavanje složenih problema, kao i naučno određivanje varijanti rešenja.

Korišćenje naučnih metoda, tehnika, informatičke opreme i softvera pri planiranju obezbeđuje objektivnost planiranja, maksimalno iskorišćavanje mogućnosti planiranja aktivnosti i kvantifikaciju ciljeva. ${ }^{16}$ Poželjno je da planovi budu formulisani u pisanoj formi. Sistem, pojave i procesi se posmatraju tokom planiranja kroz čitav životni ciklus, uz obuhvat svih činilaca koji utiču na dostizanje cilja i uključivanje glavnog rukovodstva u (timski) rad na planiranju.

Sve informacije potrebne za planiranje retko će biti dostupne, što planiranje čini ograničenim i zahteva fleksibilan pristup organizaciji planiranja, sagledavanje parcijalnih rešenja i njihovu optimizaciju sa aspekta krajnjeg cilja. ${ }^{17} \mathrm{U}$

\footnotetext{
Kvantifikacija može da se izrazi kategorijama vremena, određenim iznosom troškova, pomoću količinskih odnosa, stepena ili procenta.

${ }^{17}$ Budućnost je neprekidan tok događaja koji se mogu predvideti i na koje se može uticati sprovođenjem planskih odluka, koji se mogu sagledati i na koje se ne može uticati i koji se niti mogu sagledati niti se može na njih uticati.
}

procesu iznalaženja planskih rešenja potrebno je analizirati prošlost, ocenjivati sadašnjost i predviđati budućnost, uz prihvatanje verovatnoće kao mere preciznosti predviđanja budućih stanja. Korišćenje razvijene (stvorene) baze znanja, pri planiranju, „ugrađivanje“ pravih informacija u planove i isticanje težišta i prioriteta u planskim rešenjima proces planiranja čini racionalnim.

Planiranje se obavlja osloncem na postojeća znanja, uglavnom predstavljena u pisanoj formi (podaci za upotrebu), kao i na iskustvo, pri čemu se uvažavaju istorijski razvoj objekta - pojave posmatranja (primena kvantitativnih metoda), ali i moguće turbulentno ponašanje u sistemu i okruženju (primena kvalitativnih metoda: metode scenarija i dr.). Faze, aspekti i dimenzije sistema - problema pri planiranju se uvažavaju u meri koja će obezbediti obuhvat svih činilaca koji utiču na dostizanje cilja.

Planiranjem se sagledava mogućnost sprovođenja planova (orijentisanost plana na akciju), instrumenti i način provere ostvarenja planskih zadataka i stvaraju se uslovi za obezbeđenje kontrolnih informacija o dinamici i stanju izvršenja plana. Planovi kao instrumenti planskih odluka moraju biti formalno i sadržajno tako oblikovani da se mogu jednostavno $\mathrm{i}$ brzo menjati $\mathrm{u}$ toku planskog perioda $\mathrm{u}$ skladu sa promenama uslova funkcionisanja sistema i izvršavanja zadataka i treba da sadrže potpune, istinite i korisne informacije, potrebne dubine i stepena konkretizacije. Forma i sadržaj planova treba da budu što više tipizirani, u skladu sa jedinstvenim sistemom upravljačke dokumentacije u vojnoj organizaciji. Bit- 
ni stručni prilozi uz planske instrumente moraju se vizuelno fiksirati (napisati, nacrtati, slikati).

Uključivanjem u izradu plana onih koji planove sprovode i onih koji upravljaju njihovom realizacijom sagledavaju se sve potrebe, mogućnosti i želje i smanjuje se broj subjekata i objekata koji učestvuju u lancu informacionih i materijalnih tokova i povećava stepen motivacije za sprovođenje plana.

Svako plansko rešenje mora da predvidi neophodno rezervno vreme za izvršenje hitnih zadataka i poslova koji neizbežno iskrsavaju u realnom sistemu, a koji ne mogu da se sagledaju u početnim fazama planiranja - upravljačka vremenska rezerva. Normativi vremena i resursa pri planiranju treba maksimalno da se koriste. Detalji planskih rešenja zavise od vrste plana i upravljačkog nivoa na kojem se plan izrađuje.

\section{Faze i dimenzije planiranja}

Planiranje je kreativan stvaralački proces koji, s obzirom na suštinu [4], obuhvata:

- misaono-stvaralačke aktivnosti aktivnosti predviđanja, odlučivanja i stvaranja planskih rešenja, i

- aktivnosti tehničkog karaktera, usmerene na razna fizička merenja, rad na računaru, vođenje pribeleški i evidencija, kucanje teksta, crtanje sadržaja, izradu skica $i$ šema $i$ ispunjavanje planskih obrazaca.

Funkcionalno posmatrano, planiranje se odvija putem tri grupe usklađenih $\mathrm{i}$ srodnih poslova: predviđanje, odlučivanje i izradu planova. Među ovim zavi- snim grupama aktivnosti ne postoji stroga vremenska granica, jer se delimično odvijaju paralelno i sa međusobnim povratnim uticajem jedne na drugu.

Predviđanje obuhvata određivanje budućih stanja, ponašanja, redosleda akcija, događaja i procesa, kao i šta treba uraditi i koja akcija obezbeđuje najmanje posledice ako se desi nepredviđeno. Suština predviđanja jeste sagledavanje uticajnih faktora i elemenata situacije, budućih događaja i pojava koje treba uzeti u obzir u izradi planova i konkretizaciji postavljenih ciljeva. ${ }^{18}$ Utvrđivanje zakonitosti nastajanja i kretanja pojava, budućih stanja i ponašanja može se vršiti kvalitativno, eksperimentom, kvantitativnom analizom i primenom iskustva.

Odlučivanje je misaoni proces koji obuhvata celokupnu delatnost pri rešavanju nekog problema. ${ }^{19}$ Donošenje odluke u okviru planiranja zahteva analizu i upoređivanje više varijanti rešenja po više kriterijuma različitog uticaja i različitog nivoa značajnosti i uvažavanje realnih ograničenja. Za neki problem može postojati više varijanti rešenja, ali odluka za jedan zadatak može biti samo jedna i predstavlja akt opredeljenja funkcionalnog autoriteta (pravo na odlučivanje) na tehnologijom odlučivanja iznađena rešenja. Finalni produkt izbora jedne varijante predstavlja odluku. ${ }^{20}$

Formulisanje odluka upravljanja $u$ procesu planiranja ostvaruje se izradom plana. Izradom planova misaono oformlje-

\footnotetext{
${ }^{8}$ Od kvaliteta predviđanja u znatnoj meri zavisi realnost planova. Predviđanja za duži vremenski period nesigurna su, i što je zadati cilj kompleksniji to je i rizik veći.

${ }^{19}$ Donošenje odluke je iterativna procedura sa nekoliko ciklusa u kojoj svaki ciklus opet ima nekoliko koraka. će varijante.
} 
na rešenja se pomoću određenih tehnika izrade plana oblikuju, konkretizuju i materijalizuju. Planovi se oformljuju tekstualno, tabelarno, grafički i kombinovano. Plan predstavlja akt nužnosti - zakon u materijalnom pogledu i obavezujući je za izvršioce zadatka. Izradom planova konkretizuju se ciljevi i bliže određuje šta sve treba preduzeti da bi se ciljevi dostigli.

Plan kao instrument procesa planiranja predstavlja razradu kvalitativnih i kvantitativnih pokazatelja o zadacima koji proističu iz namene sistema i ciljeva poslovanja. Plan je jedan od bitnih instrumenata upravljačke funkcije koji služi kao podloga za preduzimanje upravljačkih akcija. Izradom planova vrši se konkretizacija ciljeva i bliže određuje šta sve treba preduzeti da bi se ti ciljevi mogli ostvariti, imajući u vidu verovatni razvoj budućih događaja.

Konkretizacija ciljeva obuhvata odgovore na pitanja: šta treba uraditi; ko treba da izvrši pojedine zadatke; kada šta treba da uradi; gde i kojim sredstvima i kako treba da uradi.

Generalno posmatrano, dobar plan treba da sadrži želje, potrebe i mogućnosti, jer da bi se planiralo moraju se poznavati sopstvene potrebe, preispitati sopstvene mogućnosti, a nešto se mora $\mathrm{i}$ želeti.

U vojnim organizacionim sistemima planove karakterišu sledeće dimenzije: prostorna, vremenska i organizaciono-tehnološka.

Prostorna dimenzija podrazumeva odvijanje određenih aktivnosti na konkretnom prostoru, određenom donetim odlukama ili mestom lociranja, odnosno angažovanja resursa. Prostornu dimenzi- ju je, pri izradi planskih rešenja, najbolje predstaviti na računaru ,3D prikazom“ $i$ na topografskoj karti (na koju se unosi razmeštaj bitnih elemenata $i$ važni podaci), skicama i šemama.

Vremenska dimenzija planiranja pokazuje da svaka aktivnost ima određeno trajanje i da se mora odvijati u određenom vremenu, u odnosu na određene vremenske repere i ograničene resurse. Ova dimenzija planiranja može se najbolje izraziti linijskim dijagramima aktivnosti gantogramima aktivnosti.

Organizaciono-tehnološka dimenzija podrazumeva odvijanje aktivnosti na način i u vremenu određenom njenim logičnim mestom u okviru zadatka, odnosno celog projekta. Najbolje se može predstaviti mrežnim planom podržanim sa linijskim dijagramima i određenim slobodnim formama prozne deskripcije (opisno). Često se koristi terminski mrežni plan (kao instrumentarij za određivanje tehnologije izvođenja aktivnosti) koji pruža informacije o: zadacima i njihovim nosiocima; terminiranju zadataka; raspodeli resursa po zadacima i ulazno-izlaznim parametrima aktivnosti (tamo gde je to potrebno).

\section{Sagledavanje upravljanja putem planiranja}

Upravljanje u vojnim organizacionim sistemima predstavlja usmeravanje i koordinaciju ljudskih, materijalnih i drugih resursa da bi se ciljevi dostigli u planiranom vremenu, u planiranom obimu, sa planiranim troškovima i da bi bili planiranog kvaliteta. Njime se obezbeđuje jedinstveno postupanje i homogena akcija. 
Da bi se aktivnosti organizacionih procesa odvijale po zahtevanoj tehnologiji i da bi se njima upravljalo moraju se, $u$ procesu planiranja, sagledati i osigurati svi potrebni ulazni i izlazni parametri organizacionih aktivnosti, što se vidi na slici.

Problemi većine organizacionih sistema ne proizlaze iz organizacione već iz procesne strukture, najčešće zbog nepovezanih aktivnosti ili procesa međusobno. Tehnologija sprovođenja organizacionih procesa ne zasniva se samo na određivanju logičke međuzavisnosti aktivnosti već i na određivanju protoka izlaznih parametara prethodne aktivnosti u ulazne parametre kod narednih aktivnosti. Da bi izvršioci mogli realizovati aktivnosti neophodno je da imaju sve programske informacije, ulazne strukturne informacije $\mathrm{i}$ osiguran ulazni materijalni tok. Takođe, neophodno je da znaju kome treba da dostavljaju izlazne strukturne informacije, izlazne materijalne tokove i izveštaje.

Aktivnosti $\mathrm{u}$ vojnim organizacionim sistemima izvode pojedinci, grupe, tehnološke celine i ekipe koje su organizaciono, preko svojih rukovodstava, uvezani u određene organizacione celine i jedinice. Da bi svaka organizaciona celina ili pojedinac izvršilac mogao da realizuje određene aktivnosti neophodni su mu podaci i informacije. Takođe, i rukovodstvu koje upravlja kompletnim organizacionim procesom neophodne su određene informacije. Potrebne informacije obezbeđuju se putem horizontalnog i vertikalnog informisanja.

Da bi se uspešno upravljalo realizacijom aktivnosti u vojnim organizacionim sistemima neophodno je, na osnovu programa (organizacije i tehnologije), izvođenja, obezbediti sve potrebne informacije o planskim aktivnostima (programske informacije), kako bi se moglo narediti - aktivirati njihovo sprovođenje i obezbediti da se pri kontroli sprovođenja aktivnosti dobiju projektovani izlazni parametri i rezultati aktivnosti koji se mogu upoređivati sa ulaznim parametrima. Uspešno odvijanje procesa u vojnim organizacionim sistemima zahteva obezbeđenje prenosa svih parametara i rezultata prethodnih aktivnosti u sledeće aktivnosti.

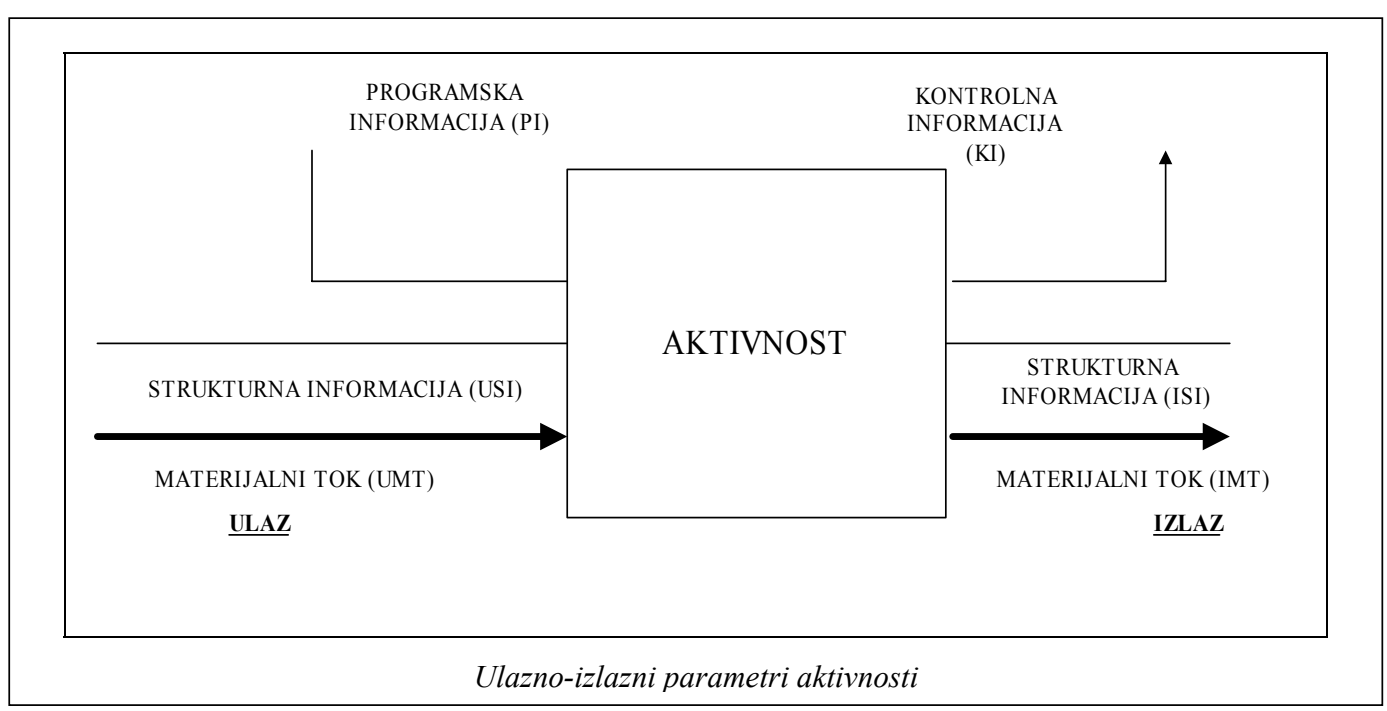


Ako u toku realizacije dođe do kasnijeg ili ranijeg završetka aktivnosti neophodno je doneti odluku o daljem toku odvijanja aktivnosti i promeni koja se mora provesti (na primer, skraćenje aktivnosti na kritičnom putu ili raniji početak neke aktivnosti), odnosno promeniti programske informacije aktivnosti, a zatim sprovesti vertikalnu i horizontalnu informisanost.

Raspoloživi resursi u vojnim organizacionim sistemima su ograničeni, pa je neophodno da se planiranjem i upravljanjem reši problem njihovog optimalnog raspoređivanja $i$ da se postavi informaciona osnova za njihovo obezbeđenje po količini, kvalitetu i rokovima.

Suština optimalne raspodele ograničenih resursa, u funkciji vremena, na izvršenje bilo koje aktivnosti projektuje se u toku planiranja početka svake aktivnosti, koje pri zadatim ograničenim resursima obezbeđuje izvršenje zadatka u najkraćem roku, pri čemu se uzima u obzir tehnološka zavisnost aktivnosti. Optimalno rešenje angažovanja resursa uslovljeno je usvojenim kriterijumom optimizacije i prisutnim ograničenjima (ograničavajućim uslovima), a može se obavljati uz uvažavanje sledećih kriterijuma: da se za čvrsto zadati rok, uz poznati obim i vrstu zadataka, iznađe optimalni plan angažovanja resursa; da se za čvrsto zadate resurse, poznati obim i vrstu zadataka odredi minimalno trajanje izvršenja zadatka; da se za poznate raspoložive resurse $\mathrm{u}$ zadatom intervalu iznađe vrsta $\mathrm{i}$ obim zadataka koje je moguće realizovati uz postizanje maksimalnih efekata (ekonomskih i drugih).

\section{Tehnike, metode i softver za podršku planiranju}

Postoje brojne metode, tehnike i softver koji se mogu koristiti pri planiranju u vojnim organizacionim sistemima [2]. U konkretnoj situaciji treba ih pravilno izabrati prema predmetu, svrsi, zadatim ciljevima i raspoloživoj naučnoj građi - činjenicama. Njihovom primenom znatno se doprinosi efikasnosti i efektivnosti planiranja, ali i realizaciji planiranih poslova.

Poznatiji softveri za podršku pojedinih faza procesa planiranja poslova projektne prirode su:

- MICROSOFT EXCEL - namenjen za rad sa bazama podataka (kreiranje, upravljanje, ažuriranje). Omogućava izradu raznih tabela i grafikona zasnovanih na podacima iz radnih tabela, rad sa bazama podataka u tabelarnom obliku, različite operacije nad tabelarnim podacima i kreiranje različitih vrsta i formi izveštaja (tabelarna forma, ciklogrami, histogrami, kumulativni prikazi...);

- ACCESS - namenjen je za rad sa bazama podataka (kreiranje, upravljanje, ažuriranje). Omogućava korišćenje automatizovane aplikacije baze podataka iz interaktivne baze podataka. U njemu je ugrađena zbirka korisnih ,alatki“ koje olakšavaju pravljenje pojedinih komponenti baze podataka (tabele za smeštaj podataka, upiti, obrasci i izveštaji). Posebne mogućnosti softvera u oblasti automatizacije baze podataka jesu kreiranje modula i makroa;

- POLICU/GOAL PERCENTAGING - namenjen za rešavanje problema višekriterijumskog odlučivanja;

- IFPS/Personal (Interactive Personal Financial Planning System) - name- 
njen za potrebe interaktivnog finansijskog planiranja, koji omogućava i primenu u drugim oblastima. Omogućava analizu osetljivosti, analizu ,šta-ako“ i analizu dostizanja cilja;

- COAL PROGRAMING - koristi se za rešavanje problema ciljnog linearnog programiranja;

- MODSIM III - objektno orijentisan modularan simulacioni jezik, blok strukture i opšte namene, sa mogućnostima za vizuelnu prezentaciju simulacija. Namenjen je za upotrebu u izradi velikih procesno baziranih modela simulacije izolovanih događaja putem modularnih i objektno orijentisanih tehnika razvoja. Kao izlaz može dati izvršni program sa simulacionim eksperimentom. Jezik je građen otvoreno, tako da se može proširivati sa modulima za baze podataka, posebno za građenje distribuiranih simulacionih igara i dr.;

- VKR - programski paket namenjen za rešavanje problema višekriterijumskog odlučivanja. Softver sadrži sledeće metode: MISEL, Elektre I i II, IKOR, Promethee I, II i III, MENOR, TOPSIS;

- VP - EXPERT - namenjen je za implementaciju ekspertnih sistema. Omogućava korišćenje postojeće i pravljenje nove baze znanja;

- EXPERT CHOISE - pogodan je za rešavanje problema višeatributnog odlučivanja gde se javlja više konfliktnih i konkurentnih kriterijuma i više alternativa. Omogućava analizu ,sta-ako“, analizu osetljivosti rešenja i određivanje indeksa konzistentnosti donosioca odluke. Softver predstavlja simbiozu matematičke metode analitičkih hijerarhijskih procesa $\mathrm{i}$ elemenata ekspertnog sistema $\mathrm{u}$ obliku generatora sistema za podršku odlučivanju (SPO). Može da se koristi za modeliranje i rešavanje različitih vrsta problema, kod grupnog odlučivanja i odlučivanja sa većim brojem kriterijuma i alternativa;

- CA SPJ - namenjen je za planiranje, praćenje i upravljanje projektima. Omogućava rad sa velikim brojem aktivnosti determinističkog i stohastičkog karaktera, izradu kalendara aktivnosti i resursa, raspored poslova prema prioritetu aktivnosti i resursa $\mathrm{i}$ istovremeni rad sa više projekata;

- MICROSOFT PROJECT - namenjen je za planiranje, praćenje i upravljanje projektima, sa aktivnostima stohastičkog i determinističkog karaktera. Omogućava rad sa standardnim kalendarima aktivnosti i resursa i formiranje kalendara po sopstvenoj želji. Pruža mogućnost rada sa ograničenjima, definisanje različitih odnosa među povezanim zadacima i predhođenje i odlaganje povezanih zadataka - aktivnosti. Omogućava veliki broj operacija nad unetim podacima (traženje, pretraživanje, ažuriranje, filtriranje, sortiranje), kao $i$ istovremeni rad sa više projekata;

- PROGRAMSKI PAKET PRIMAVERA - koristi se za planiranje, praćenje i upravljanje projektima.

Raspoložive činjenice, složenost i vrsta problema znatno uslovljavaju izbor metode ili softvera za podršku planiranju.

\section{Zaključak}

Vojni organizacioni sistemi funkcionišu u doba neizvesnosti i brzih promena, a osnove na kojima se zasnivaju planovi vrlo su nesigurne. Ipak, planiranje 
je i u tim uslovima i nužnost i potreba, a u uslovima neizvesnosti upravo je obaveza i izazov za kompetentno rukovodstvo i planske organe.

Promene koje se dešavaju na globalnom planu, u okruženju vojnih organizacionih sistema, zahtevaju drugačiji pristup planiranju, dinamičko sagledavanje budućnosti i napuštanje klasičnog pristupa, uvažavanje teorijskih saznanja i primenu savremenih metoda i tehnika, softvera i opreme.

Planiranje je obaveza menadžmenta i planskih organa, a planski organi snose odgovornost i za svoj rad. U vojnim organizacionim sistemima planiranjem se bave pojedinci i grupe, a najbolje je ako se planira timski. Planiranje treba da predstavlja neprekidan proces, a ne parcijalnu delatnost u trenutku nužnosti. Zbog značaja planiranja za vojne organizacione sisteme u strukturi moderno organizovanih vojski formiraju se posebne organizacione celine, sastavljene od vrlo obrazovanih profesionalaca, koji se bave ovim veoma osetljivim i za sistem značajnim poslom.

Komparativne prednosti na kojima treba zasnivati planiranje jesu: znanje, iskustvo i kvalitet, a oni trenutno nisu koncentrisani u sistemu već imaju znatnu disperziju. Planiranje koje se svodi na puku rutinu ili zadovoljenje formalnih obaveza, bez definisane koncepcije razvoja, nema nikakvog smisla. Efikasnijim i na naučnoj osnovi zasnovanim planiranjem postigao bi se viši kvalitet planskih rešenja, racionalno trošenje i opterećenje resursa i time dao značajan doprinos podizanju nivoa gotovosti Vojske.

Planiranje kao proces rešavanja organizacionih problema ima više aspeka- ta: organizacioni, metodološki, komunikacioni, međuljudski i funkcionalni (sadržajni), a njihovim ovladavanjem znatno se doprinosi kvalitetu planiranja. Da bi se uspešno upravljalo funkcionisanjem vojnih organizacionih sistema vrlo je bitno da se još u fazi planiranja razmišlja o informacijama potrebnim za upravljanje sistemima i procesima.

Vojni organizacioni sistem mora da zadovolji neprekidnost funkcionisanja, što podrazumeva da kroz neprekidno $\mathrm{i}$ organizovano planiranje, praćenje stanja, relevantnih faktora i elemenata situacije i preduzimanje upravljačkih akcija treba da spreči moguća iznenađenja i bude uvek spreman za iznalaženje adekvatnih rešenja.

Stalno prisutan zahtev za jedinstvom komandovanja i smanjenjem brojnog stanja komandi i uprava, uz istovremeno povećanje operativnosti u radu i kvalitetu planskih rešenja, može se zadovoljiti samo primenom teorijskih dostignuća u oblasti planiranja, izborom adekvatnih organizacionih oblika rada u toku sprovođenja planiranja (razni oblici grupnog, a pre svega timskog rada), primenom naučno zasnovane metodologije planiranja i većom primenom naučnih metoda, tehnika, informatičke opreme i softvera.

Uočene slabosti u oblasti planiranja (kao upravljačke funkcije i kao poslovi planskih organa) zahtevaju da se planiranje u većoj meri prilagodi potrebama prakse, zahtevima vremena, savremenim upravljačkim trendovima i dinamičnim organizacionim promenama. Zbog brzine i nužnosti promena, moraju se uspostaviti mehanizmi koji će reagovati na prome- 
ne, koje treba uočavati i prepoznavati, čak i u vidu slabih signala. Pored toga, uz puno znanja, rada i učenja, mora se menjati vlastiti način razmišljanja, odnos prema filozofiji, kulturi i klimi vojne organizacije.

\section{Literatura:}

[1] Kukoleča, N.: Organizaciono-poslovni leksikon, Rad, Beo$\operatorname{grad}, 1986$

[2] Andrejić, M.: Timski rad u vojnim organizacionim sistemima, Vojno delo broj 3/2001. (str. 83 do 108), Beograd, 2001.
[3] Andrejić, M.: Metode i softver za podršku planiranja u logističkim organizacionim sistemima, Vojnotehnički glasnik broj 1/2001. (str. 36 do 53), Beograd, 2001.

[4] Jovanović, B.: Uvod u teoriju vojnog rukovođenja, VIZ, Beograd, 1984.

[5] Stokke, P., Ralston, W., Boyce, T., Wilson, Y.: Scenario planning for norwegian oil and gas, Long range planning, No 2, 1990.

[6] William R. Duncan.: A guide to the project management body of knowledge, pmi Standards Committee, 1996.

[7] Uputstvo o planiranju rada u VJ, GŠ VJ, Beograd, 1998.

[8] Weihrich, H. Koontz, H.: MANAGEMENT, McGraw-Hill, inc., International Edition, 1993.

[9] Certo, S.: PRINCIPLES OF MODERN MANAGEMENT, FUNCTION AND SYSTEMS, Allin and Bacon, BOSTON, LONDON, SYDNEY, TORONTO, 1989. 